\title{
PELATIHAN KEWIRAUSAHAAN BAGI PELAKU USAHA KECIL DAN BINAAN KOPERASI DI RUMAH SUSUN SEDERHANA SEWA (RUSUNAWA) CIPINANG BESAR SELATAN
}

\author{
Dewi Susita \\ Universitas Negeri Jakarta \\ dewisusita@yahoo.com \\ Umi Mardiyati \\ Universitas Negeri Jakarta \\ umi.mardiyati@gmail.com \\ Hania Aminah \\ Universitas Negeri Jakarta \\ hania@unj.ac.id
}

\begin{abstract}
In an effort to improve empowerment of creative economy, enterpreneurship and management for small business and cooperation is the basis for author to improve the empowerment through training. Training is one of the way to improve the competence of people for generating optimal performance that suitable with the expectation. The study was conducted by using survey method with interview, observation techniques, and questionnaires. The title of this community service activity is Enterpreneurship Training for Small Business and Cultivated Cooperative at Rusunawa Cipinang Besar Selatan. The purpose of this activity is to develop an improve the enterpreneurship as well as improving the management skills of small business and cooperation at Rusunawa Cipinang Besar Selatan. This activity are developing enterpreneurship, market and marketing analysis, business management, partnership, production efficiency, financial management, and business proposal can be useful in developing the business.
\end{abstract}

Key words: Enterpreneurship,Management, Small Business and Cooperation

\section{PENDAHULUAN}

Selama periode krisis ekonomi yang dihadapi Indonesia sampai saat ini, sektor Usaha Kecilterbukti mampu berkembang dan semakin memantapkan peranan pentingnya dalam 
memperingan beban pemerintah baik dalam penghematan devisa, penyediaan lapangan kerja bagi angkatan kerja baru ataupun para korban PHK perusahaan-perusahaan konglomerasi yang terus bertambah jumlahnya, maupun dalam meningkatkan efisiensi perekonomian nasional.Oleh sebab itu sudah sepantasnya pemerintah memberi perhatian yang lebih serius dan harus memelihara komitmen yang kuat untuk membina dan mengembangkan sektor usaha kecil. Terciptanya kondisi perekonomian rakyat yang kuat akan dapat mengurangi ketergantungan negara pada sumbersumber dari luar yang telah sangat memberatkan selama ini yang menjadi pemicu utama krisis ekonomi yang berkelanjutan.

Salah satu cara untuk meningkatkan jumlah usaha di Indonesia umumnya dan di lingkungan Kelurahan Rawamangun khususnya adalah dengan meningkatkan sektor kewirausahaan, sehingga banyak muncul pengusaha - pengusaha baru yang handal dan potensial.

Dalam era globalisasi sekarang ini tingkat persaingan semakin tinggi baik dalam mencari pekerja maupun dalam mencari peluang pendapatan.Oleh karena itu kita tidak bisa tergantung kepada pemerintah, tapi hendaknya ada keinginan untuk berwirausaha. Salah satu cara berwirausaha adalah terlebih dahulu kita harus mempunyai jiwa berwirausaha dan mempunyai motivasi untuk berwirausaha, oleh karena itu perlu adanya pelatihan berwirausaha ini.
Pembinaan dan pengembangan usaha dengan menunbuhkan jiwa wirausaha dan meningkatkan kemampuan berusaha ke depan, haruslah dilakukan dengan penataan ulang segala aspek, kebijakan dan prosedur dari sistem yang telah diterapkan selama ini baik secara nasional maupun regional dan lokal. Berbagai komplikasi kebijakan dan prosedur serta program yang ada harus dipangkas. Bidang usaha difokuskan pada penciptaan produk dan jasa yang diminta pasar baik pasar input maupun pasar output dengan mengandalkan keunggulan kompetitif. Informasi dan komunikasi antar pembina dan yang dibina haruslah lebih tepat guna yang terarah pada permintaan pasar dan proses dalam menjangkau pasar. Perlunya diterapkan seleksi rasional dalam penyaluran bantuan, penerapan kebijakan pengawasan mitra binaan dengan ukuran-ukuran yang dapat memotivasi kearah pengelolaan bisnis secara profesional, adaptif dan responsif terhadap perubahan lingkungan. Sebagai basis penting untuk maksud tersebut, harus diupayakan tumbuhnya image dan kesadaran dari masyarakat bahwa program pembinaan yang dilakukan didasarkan atas azas manfaat secara ekonomi bukannya bersifat sosial menurut pengertian umum yang ada.

Bagi wilayah Rawamangun, pembinaan dan pengembangan usaha dan kewirausahaan adalah suatu fakta yang tidak perlu diperdebatkan lagi tentang penting tidaknya upaya 
tersebut. Hal ini mengingat suatu tradisi bisnis yang melekat kuat pada umumnya masyarakat daerah ini, yang dicerminkan oleh 95\% dari masyarakat yang berada di DKI Jakarta pada umumnya adalah pengusaha.

Upaya mewujudkan unit-unit usaha rakyat yang tangguh dan mandiri dengan prinsip manajemen bisnis yang berorientasi pasar, kredibel, dan bertanggungjawab semakin mendesak saat ini guna menghadapi era liberalisasi pasar yang sudah di depan mata.

Permasalahan pada umumnya yang mengitari pengusaha-pengusaha tersebut yang menghambat pertumbuhannya meliputi beberapa hal mendasar seperti; lemahnya mental berwirausaha, ketertutupan dan ketidakjelasan entitas, akuntabilitas, pemasaran, keterikatan yang kuat pada tradisi sehingga kurang tanggap dan adaptif terhadap tuntutan perubahan, ketertinggalan tehnologi, dan cenderung mengabaikan mutu. Permasalahan ini mencuat kepermukaan sejalan dengan kondisi lingkungan bisnis yang semakin kompleks dan penuh ketidakpastian pada akhir-akhir ini dan ke depan. Oleh karena itu perlu diupayakan program berkelanjutan untuk menumbuhkan mentalitas dan budaya bisnis, kreativitas disain produk, penyerapan kemajuan tehnologi, serta pengetahuan dan ketrampilan manajerial yang sesuai dengan tuntutan lingkungan bisnis yang terus berubah.
Kemiskinan diartikan sebagai ketidakberdayaan sekelompok masyarakat atas sistem pemerintahan yang menyebabkan masyarakat berada pada posisi yang tereksploitasi. Hal ini menggambarkan bahwa kemiskinan adalah kondisi pola hidup, budaya, dan pola-pola interaksinya bukanlah sesuatu yang terberi, namun tercipta karena adanya peran struktur yang menindas (Huri, 2009). Wacana dominan yang menyatakan bahwa perempuan tidak perlu mandiri secara ekonomi, telah menjadi penyebab utama keterkaitan perempuan dan kemiskinan. Faktor pendidikan telah menjadi bagian dari upaya ketidakmandirian perempuan secara ekonomi.

Untuk itu, perlu pengembangan kapasitas bagi perempuan secara berkesinambungan. Selama kondisi perempuan masih terpuruk dan diwarnai kerentanan akibat ketidakadilan jender yang dihadapinya, negara dan masyarakat mempunyai tanggung jawab untuk melakukan berbagai upaya agar hak perempuan sebagai anggota masyarakat terpenuhi. Berbagai bentuk ketidakadilan jender, seperti marjinalisasi, diskriminasi, kekerasan, stereotip, multi beban, dan subordinasi harus dapat segera dihilangkan (Nugroho, 2008:163). Keterlibatan perempuan dalam program pembangunan seperti, penguatan ekonomi danpeningkatan kualitas sumber daya manusia diharapkan dapat terwujud. Perlu strategi pemerataan yang meliputi, pemerataan di tingkat kesejahteraan, tingkat akses, tingkat 
penyadaran, tingkat partisipasi aktif, dan tingkat kontrol/kekuasaan.

Mengapa perlu memotivasi perempuan agar melakukan peluang kerja produktif dan mandiri, pertama, perempuan adalah asset potensial yang hingga saat ini kurang diperhatikan negara; kedua, dengan memberdayakan perempuan diharapkan menjadi agen perubahan untuk kemajuan ekonomi secara umum. Pemberdayaan perempuan yang dicanangkan Millenium Development Goals dalam mengurangi kemiskinan bagi perempuan memiliki tiga dimensi: yaitu human capability, kemampuan manusia dalam hal pendidikan, kesehatan dan gizi dengan menghilangkan gap pendidikan bagi perempuan dan laki-laki hingga sekolah menengah; acces to resources and opportunity, akses terhadap sumber daya dan kesempatan yang mengacu pada aset ekonomi dan partisipasi politik; dan security, terutama kerentanan perempuan terhadap kekerasan. Pemberdayaan perempuan dapat dilakukan dengan pendekatan pembangunan berbasis hak, bahwa setiap orang memiliki berbagai hak yang mendasar yang sama setiap negara wajib untuk memajukan, meningkatkan, dan melindungi hak-hak warga negaranya, untuk hidup layak (Sen, 1999).

Di sisi lain, masalah kemiskinan di daerah perkotaan juga perlu mendapat perhatian. Krisis ekonomi tahun 1997 memperlihatkan masyarakat kota masih rentan untuk jatuh ke bawah garis kemiskinan. Persentase penduduk miskin di perkotaan juga cenderung untuk terus meningkat. Pada umumnya masyarakat miskin perkotaan menjalani pengalaman kemiskinan yang berbeda dengan penduduk miskin pedesaan. Mereka lebih banyak mengalami keterisolasian dan perbedaan perlakuan dalam upaya memperoleh dan memanfaatkan pelayanan pendidikan dan kesehatan serta ketidakamanan seperti penggusuran. Tindakan memotivasi perempuan melalui pemberdayaan perempuan dapat menekan angka kemiskinan dengan mengubah dan memperbaiki hidup sebagai agent of change bagi perempuan.

Oleh karena itu, dalam kegiatan pelaksanaan Pengabdian Masyarakat kali ini, para dosen di Program Studi S1 Manajemen Fakultas Ekonomi Universitas Negeri Jakarta merasa tertarik untuk melakukan pelatihan jiwa kewirausahaan bagi para pelaku usaha kecil dan binaan koperasi, sekaligus memberikan motivasi agar usaha yang sedang dikembangkan dapat terus bertahan serta berdaya saing di tengah persaingan yang begitu ketat.

\section{Perumusan Masalah}

Pentingnya upaya menumbuhkan dan memotivasi para warga sekitar sebagai sumber daya potensial, permasalahan dalam lingkup ini menekankan pada:

1) Bagaimanacara mengembangkan dan meningkatkan jiwa kewirausahaan pelaku usaha kecil dan 
binaan koperasi di Rumah Susun Sewa Kelurahan Rawamangun?

2) Bagaimana cara meningkatkan pengetahuan manajemen pelaku usaha kecil dan binaan koperasi di Rumah Susun Sewa Kelurahan Rawamangun?

\section{Tujuan Kegiatan}

Tujuan kegiatan ini antara lain:

1. Mengembangkan dan meningkatkan jiwa kewirausahaanpelaku usaha kecil dan binaan koperasi di kelurahan Rawamangun.

2. Meningkatkan keterampilan pelaku usaha kecil dan binaan koperasi di Rumah Susun Sewa Kelurahan Rawamangun.

\section{Manfaat Kegiatan}

Manfaat dilakukannya kegiatan ini, antara lain:

1. Diharapkan memiliki jiwa kewirausahaan bagi pelaku usaha kecil dan binaan koperasi yang baik sehingga dapat terus mengembangkan usaha dengan baik.

2. Diharapkan memiliki pengetahuan manajemen dalam mengembangkan dan membina koperasi untuk mencapai hasil yang optimal.

\section{Sasaran Kegiatan}

Sasaran dalam kegiatan ini adalah para pelaku usaha kecil dan binaan koperasi di wilayah DKI Jakarta khususnya di lingkungan Rumah Susun Sewa Rawamangun dengan jumlah efektif peserta sebanayak kurang lebih 100 peserta yang merupakan Usaha Kecil dan
Koperasi yang digolongkan kedalam masyarakat menengah ke bawah dianggap relevan dalam kegiatan ini.

Penghasilan yang masih minim serta persaingan yang begitu ketat kerap dianggap para pelaku menjadi sebuah ancaman dan menurunkan motivasi mereka dalam berwirausaha. Dengan demikian dengan adanya pelatihan ini maka para pelaku usaha kecil dan binaan koperasi ini mampu menjadi change agent dan pioneer bagi masyarakat lainnya untuk mengembangkan usaha.

\section{KAJIAN TEORITIK Kewirausahaan}

Kewirausahaan (entreprenurship) merupakan istilah yang sampai dengan saat ini masih terus diperbincangkan di berbagai tingkat diskusi. Dimulai pada tahun 1998 dimana terjadinya krisis moneter besar-besaran di Indonesia, kegiatan wirausaha mulai menurun karena banyak terjadi permasalahan dimanamana serta hutang yang ditinggalkan cukup besar, padahal sebelumnya wirausaha merupakan profesi kebanggaan. Kini profesi sebagai wirausaha sudah menggaung kembali seiring dengan berkembangnya perekonomian dunia khususnya di Indonesia.

Kreitner menjelaskan dalam Agustina (2015:3) kewirausahaan merupakan sebuah proses dalam menjawab tantangan dan peluang yang ada baik yang dilakukan oleh individu maupun organisasi meskipun 
dalam kondisi sumberdaya yang dimiliki terbatas. Selanjutnya dijelaskan kembali oleh Zimmerer dan Scarborough dalam Agustina (2015:3) bahwa kewirausahaan adalah seseorang yang memulai dan menciptkan suatu usaha baru dengan segala risiko dan ketidakpastian yang dihadapi dengan tujuan untuk memperoleh keuntungan serta kemampuan dalam mengidentifikasi berbagai sumberdaya yang ada untuk dapat dimanfaatkan sebagai peluang. Sehingga dapat disimpulkan bahwa kewirausahaan adalah kemampuan dari segi kognitif, keterampilan, dan sikap dalam menciptakan sebuah ide yang inovatif dengan penggunaan sumberdaya yang terbatas sekalipun untuk mencapai tujuan.

\section{Kriteria Usaha Mikro, Kecil, dan Menengah}

Kriteria yang berkaitan dengan skala usaha, disebutkan dalam Pasal 6 UU UMKM No. 20 Tahun 2008, terbagi atas tiga (3) kriteria, yakni:

\section{Kriteria Usaha Mikro}

Memiliki kekayaan bersih paling banyak Rp 50.000.000 tidak termasuk tanah dan bangunan tempat usaha dan memiliki penjualan tahunan paling banyak Rp 300.000.000;

2. Kriteria Usaha Kecil

Memiliki kekayaan bersih laba dari Rp 50.000.000 sampai dengan Rp 500.000.000 tidak termasuk tanah dan bangunan dan memiliki hasil penjualan tahunan lebih dari $\mathrm{Rp}$
300.000.000 sampai Rp

2.500.000.000;

\section{Kriteria Usaha Menengah}

Memiliki kekayaan bersih lebih dari Rp 500.000.000 sampai dengan paling banyak Rp 10.000.000.000 tidak termasuk tanah dan bangunan dan memiliki penjualan tahunan lebih dari Rp 2.500.000.000 sampai $\mathrm{Rp}$ 50.000.000.000.

Peranan Kewirausahaan dan Usaha Kecil dan Menengah (UKM) pada Perekonomian Nasional

Tercatat kontribusi usaha kecil di beberapa Negara maju seperti halnya di Amerika Sertikat yang mampu menyerap tenaga kerja sampai dengan $58 \%$ dan $40 \%$ GDP hasil dari sumbangan usaha kecil, namun hal tersebut juga tidak hanya di Negara maju tetapi juga di Negara berkembang yang memiliki peran yang cukup tinggi dalam kontribusi yang positif terhadap penanggulangan masalah-masalah ekonomi dan sosial, berupa tingginya tingkat kemiskinan, besarnya jumlah pengangguran, ketimpangan distribusi pendapatan, dan lainnya.

Sehingga diaktakan oleh Lupiyoadi dalam Agustina (2015:6) bahwa dampak sosio-ekonomi dari adanya wirausaha, adalah:

1. Menciptakan lapangan kerja;

2. Meningkatkan kualitas hidup;

3. Meningkatkan pemerataan pendapatan; 
4. Memanfaatkan dan memobilisasi sumber daya untuk meningkatkan produktivitas Nasional;

5. Meningkatkan kesejahteraan pemerintah melalui program pemerintahan seperti pajak.

\section{Strategi Pengentasan Kemiskinan}

Kemiskinan adalah ketidaksamaan kesempatan untuk mengakumulasikan basis kekuasaan sosial. Basis kekuasaan sosial meliputi: a) modal produktif atau aset (tanah, perumahan, alat produksi, dan kesehatan); b) sumber keuangan (pekerjaan, kredit); c) organisasi sosial dan politik yang dapat digunakan untuk mencapai kepentingan bersama (koperasi, partai politik, dan organisasi sosial); d) jaringan sosial untuk memperoleh pekerjaan, barang, dan jasa; e) pengetahuan dan keterampilan; dan f) informasi yang berguna untuk kemajuan hidup (Friedman dalam Suharto, dkk., 2004: 6).

Cox (2004:1-6) membagi kemiskinan ke dalam beberapa dimensi: 1) kemiskinan yang diakibatkan globalisasi. Globalisasi menghasilkan pemenang dan yang kalah. Pemenang umumnya adalah negara-negara maju. Sedangkan negara-negara berkembang seringkali semakin terpinggirkan oleh persaingan dan pasar bebas yang merupakan prasyarat globalisasi; 2) kemiskinan yang berkaitan dengan pembangunan. Kemiskinan subsisten (kemiskinan akibat rendahnya pembangunan), kemiskinan pedesaan (kemiskinan akibat peminggiran pedesaan dalam proses pembangunan), kemiskinan perkotaan (kemiskinan yang sebabkan oleh hakikat dan kecepatan pertumbuhan perkotaan); 3) kemiskinan sosial. Kemiskinan yang dialami oleh perempuan, anak-anak, dan kelompok minoritas; 4) kemiskinan konsekuensial. Kemiskinan yang terjadi akibat faktor-faktor eksternal, seperti konflik, bencana alam, kerusakan lingkungan, dan tingginya jumlah penduduk.

Secara umum penyebab kemiskinan dapat dikategorikan dalam tiga bentuk, antara lain:

1. Kemiskinan struktural, yaitu kemiskinan yang disebabkan oleh hal-hal yang berhubungan dengan kebijakan, peraturan maupun lembaga yang ada di masyarakat sehingga dapat menghambat peningkatan produktivitas dan mobilitas masyarakat;

2. Kemiskinan kultural, yaitu kemiskinan yang berhubungan dengan adanya nilai-nilai yang tidak produktif dalam masyarakat, tingkat pendidikan yang rendah, kondisi kesehatan dan gizi yang buruk;

3. Kemiskinan alamiah, yaitu kemiskinan yang ditunjukkan oleh kondisi alam maupun geografis yang tidak mendukung, misalnya daerah tandus, kering, maupun keterisolasian daerah.

\section{Industri Kreatif, Kreativitas, dan Pemberdayaan Ekonomi Kreatif}

Saat ini industri kreatif merupakan salah satu terma atau konsep yang paling banyak diperbincangkan di kalangan akademsi maupun 
pembuat kebijakan. Ketika peningkatan industri dan ekonomi berbasis sumberdaya alam semakin mendapat tantangan karena keterbatasan bahan, industri kreatif berbasis pengetahuan dan talenta kreatif menjadi pilihan paling masuk akal untuk menggerakkan ekonomi. Ketika industri budaya bermodal raksasa dianggap kurang bisa memeratakan keuntungan finansial bagi masyarakat, industri kreatif dipandang sebagai bentuk aktivitas yang bisa mendorong pemerataan ekonomi bagi setiap individu atau komunitas yang memiliki kreativitas.

Terlebih dahulu perlu kiranya dibuat deskripsi yang jernih tentang industri budaya dan industri kreatif, agar pemaknaannya tidak mengalami tumpang-tindih. Terma industri budaya merujuk kepada indusri yang mengkombinasikan kreasi, produksi, dan komersialisasi konten-konten kreatif yang bersifat intangible dan kultural. Konten-konten tersebut secara tipikal dilindungi oleh copyright dan bisa berbentuk industri barang maupun jasa. Industri budaya secara umum berbentuk percetakan, penerbitan dan multimedia, audiovisual, produksi lagu dan sinematografi, kerajinan, dan desain (Hesmondhalgh, 2007). Industri budaya memang lebih digerakkan oleh para pemodal/perusahaan besar yang mencari keuntungan melalui "sistem industri budaya" dengan cara memproduksi dan mendistribusikan produk budaya secara nasional (atau bahkan internasional) yang di dalamnya terdapat keseluruhan organisasi yang terlibat dalam proses penyaringan produk-produk dan ideide baru yang berasal dari personel kreatif yang berada dalam level subsistem (Granham, 1997). Sementara, terma industri kreatif menekankan pada tingkatan yang lebih luas dari aktivitas yang termasuk di dalamnya industri budaya dan semua produksi kultural atau artistik, baik yang bersifat live (seperti seni pertunjukan) maupun yang diproduksi oleh unit-unit individual. Maka, industri kreatif secara umum mencakup penyediaan produk atau jasa yang juga memuat elemen-elemen substansial dari usaha kreatif dan artistik.

Dalam konteks lingkup ini, kami akan menggunakan konsep industri kreatif sebagai bentuk usaha yang dikembangkan individu, institusi, atau komunitas berbasis pengetahuan dan kreativitas mereka, khususnya dalam hal seni pertunjukan, yang bisa memberdayakan dan mensejahterakan kehidupan mereka, bukan sekedar memberi keuntungan kepada para pemodal. Dengan pemahaman tersebut, kreativitas, inovasi, sistem dan kebijakan industri kreatif, dan ekonomi kreatif menjadi konsepkonsep utama yang banyak dibicarakan oleh para pengkaji industri kreatif.

Dengan membangun industri rumah tangga yang berasal dari sejumlah industri kecil diharapkan mampu mendorong sejumlah perempuan untuk terlibat dalam 
industri rumah tangga melalui kreativitas, keahlian, dan bakat masing-masing perempuan untuk dapat menghasilkan suatu produk yang nantinya memiliki nilai jual yang mampu meningkatkan taraf hidup keluarganya. Kreativitas, keahlian, dan bakat yang dapat dilakukan oleh masing-masing individu akan menghasilkan suatu produk industri kreatif.

Secara keseluruhan peningkatan kapasitas sumber daya manusia di lingkungan nelayan Cilincing merupakan kegiatan yang harus dilakukan agar dapat meningkatkan kehidupan kesejahteraan yang lebih baik. Instansi terkait yakni departemen Perikanan telah memberikan kegiatan penyuluhan terutamanya mengenai pengelolaan ikan asin, namun hal ini dirasakan kurang maksimal oleh semua penduduk di daerah Cilincing. Mereka mengharapkan adanya suatu pelaksanaan pendidikan keterampilan yang mampu meningkatkan taraf hidup kesejahteraannya.

\section{METODOLOGI}

Metode pelatihan yang dilaksanakan menggunakan metode tatap muka dengan pendekatan keterampilan on the job training dengan harapan agar materi yang disampaikan dapat diterima dan diterapkan dengan optimal.

\section{Materi Kegiatan}

Materi dan jumlah sesi pelatihan direncanakan seperti disarikan pada tabel 1. Setiap sesi berlangsung selama 45 menit. Jumlah sesi pelatihan direncanakan sebanyak 30 sesi, yang akan dilaksanakan selama 4 hari, dengan rencana susunan jadwal acara seperti terlihat pada lampiran 1.

Tabel 1.

Materi Dan Sesi Pelatihan

\begin{tabular}{c|l|c}
\hline \hline No. & \multicolumn{1}{|c}{ M A T E R I } & JML SESI \\
\hline \hline 1. & Pengembangan Jiwa Kewirausahaan & 3 \\
\hline 2. & Analisis Pasar dan Pemasaran & 3 \\
\hline 3. & Manajemen Usaha & 5 \\
\hline 4. & Kemitraan & 5 \\
\hline 5. & Efisiensi Berproduksi & 4 \\
\hline 6. & Manajemen Keuangan dan Proporsal Usaha & 10 \\
\hline & TOTAL SESI & $\mathbf{3 0}$ \\
\hline
\end{tabular}

\section{Metode Kegiatan}

Kegiatan ini dilakukan dengan metode kombinasi teknik tutorial, simulasi, dan latihan, serta diskusi. Porsi terbesar dari teknik kegiatan ini adalah simulasi, latihan dan diskusi. 
Tahapan Kegiatan

Kegiatan ini akan dilakukan

dalam beberapa tahap, yaitu:

a. Tahap I : Penyaringan peserta

b. Tahap II : Pelatihan

c. Tahap III : Pendampingan d. Tahap IV : Evaluasi

\section{Waktu Kegiatan}

Kegiatan ini dilaksanakan selama 3 (tiga) bulan dengan jadwal pelaksanaan sebagai berikut:

Tabel 2. Jadwal Kegiatan

\begin{tabular}{c|l|l|c|c}
\hline \multirow{2}{*}{ No } & \multicolumn{1}{|c|}{ Kegiatan } & \multicolumn{3}{c}{ Bulan } \\
\cline { 3 - 5 } & \multicolumn{1}{|c}{ I } & II & III \\
\hline 1 & Penyaringan Peserta & & & \\
\hline 2 & Pelatihan & & & \\
\hline 3 & Pendampingan & & & \\
\hline 4 & Evaluasi & & \\
\hline
\end{tabular}

HASIL DAN PEMBAHASAN

Pengabdian Pada Masyarakat (P2M) ini dilaksanakan di Kelurahan Cipinang Besar Selatan, Jakarta Timur, pada tanggal 7 Oktober 2016, dengan dihadiri oleh tim dosen pelaksana dari Jurusan Manajemen sebanyak 3 (tiga), 3 (tiga) mahasiswa serta 28 orang peserta yang merupakan para pelaku usaha yang berprofesi sebagai pedagang maupun penjahit dan lainnya. Sebelum kegiatan pelatihan tersebut dimulai, terlebih dahulu dilakukan survey berupa pembagian kuesioner yang hasilnya dapat dilihat pada tabel di bawah ini.

Tabel 3

Profil Responden

\begin{tabular}{c|l|c}
\hline No & \multicolumn{1}{|c|}{ Komponen } & Pedagang \\
\hline 1 & Usia: & - \\
& $18-23$ tahun & 1 orang \\
& $24-30$ tahun & 4 orang \\
& $31-40$ tahun & 23 orang \\
\hline 2 & $>40$ tahun & 3 orang \\
& Jenis Kelamin: & 25 orang \\
& Laki-laki & \\
& Perempuan & 1 orang \\
\hline 2 & Jenjang Pendidikan: & \\
& Tidak Sekolah & \\
\hline
\end{tabular}




\begin{tabular}{|c|c|c|}
\hline No & Komponen & Pedagang \\
\hline & SD & 2 orang \\
\hline & SMP & 1 orang \\
\hline & SLTA & 19 orang \\
\hline & Sarjana D1/D2/D3 & 5 orang \\
\hline & Sarjana S1 & - \\
\hline \multirow[t]{4}{*}{3} & Status Pernikahan: & \\
\hline & Menikah & 27 orang \\
\hline & Belum menikah & - \\
\hline & Janda/ Duda & 1 orang \\
\hline \multirow[t]{6}{*}{4} & Pendapatan per bulan: & \\
\hline & $<\operatorname{Rp} 50.000$ & - \\
\hline & $\operatorname{Rp} 50.000 \mathrm{~s} / \mathrm{d}<\operatorname{Rp} 100.000$ & - \\
\hline & $\operatorname{Rp} 100.000 \mathrm{~s} / \mathrm{d}<\operatorname{Rp} 300.000$ & - \\
\hline & $<\operatorname{Rp} 500.000$ & 27 orang \\
\hline & $\operatorname{Rp} 500.000 \mathrm{~s} / \mathrm{d}<\operatorname{Rp} 1.000 .000$ & 1 orang \\
\hline \multirow[t]{6}{*}{5} & Pengeluaran per bulan: & \\
\hline & $<\operatorname{Rp} 50.000$ & - \\
\hline & $\operatorname{Rp} 50.000 \mathrm{~s} / \mathrm{d}<\operatorname{Rp} 100.000$ & - \\
\hline & $\operatorname{Rp} 100.000 \mathrm{~s} / \mathrm{d}<\operatorname{Rp} 300.000$ & 28 orang \\
\hline & $<\operatorname{Rp} 500.000$ & - \\
\hline & $\operatorname{Rp} 500.000 \mathrm{~s} / \mathrm{d}<\operatorname{Rp} 1.000 .000$ & - \\
\hline \multirow[t]{5}{*}{6} & Sumber Pendapatan: & \\
\hline & Wirausaha & 26 orang \\
\hline & Pinjaman Koperasi & - \\
\hline & Pinjaman "bank keliling" & - \\
\hline & Pinjaman teman/tetangga/saudara & 2 orang \\
\hline
\end{tabular}

Melalui kegiatan pelatihan, para pelaku usaha kecil dan binaan koperasi mendapatkan pengetahuan dasar mengenai cara-cara yang dapat diterapkan dalam mengatur dan mengalokasikan uang yang dimiliki untuk memenuhi kebutuhan hidup mereka sehari-hari serta mengetahui bagaimana menumbuhkan jiwa kewirausahaan dan semangat dalam berwirausaha. Tim dosen pelaksana berharap agar para peserta yang hadir dapat konsisten melakukan penghematan (mengeluarkan uang hanya untuk membeli barang yang benar-benar dibutuhkan) dan memiliki perencanaan usaha ke depan yang lebih maju dan berkembang, sehingga pada akhirnya para pelaku usaha tersebut akan memiliki jumlah tabungan yang lebih besar demi meningkatkan kesejahteraan keluarga mereka serta memiliki pendapatan yang aktif.

Selain itu, kegiatan ini juga diharapkan dapat memberikan 
alternatif dan pembagian usaha/bisnis kecil-kecilan yang merata yang dapat diaplikasikan oleh para pelaku usaha kecil dan binaan koperasi, dimana saat ini kondisi yang ada usaha yang dijalankan oleh para pelaku usaha menghadapi persaingan yang cukup ketat dikarenakan beberapa diantara para pelaku usaha memiliki usaha yang sejenis, oleh karena itu alternatif dan pembagian usaha/bisnis kecil dapat menjadi dasar acuan untuk para pelaku usaha dalam memilih jenis usahanya sendiri tanpa menghambat alur usaha.

Selama pelatihan berlangsung, para pelaku usaha kecil dan binaan koperasi terlihat begitu antusias dan sangat bersemangat, terbukti dengan banyaknya pertanyaan yang diajukan, baik pada sesi diskusi dan simulasi pengelolaan keuangan maupun pada sesi terkait dengan jiwa wirausaha. Para peserta tersebut juga menyatakan bahwa mereka tertarik untuk mencoba menerapkan metode pengelolaan keuangan yang telah dipaparkan serta membuat susunan jadwal yang teratur sesuai dengan jenis usaha dan dapat lebih semangat lagi dalam berwirausaha.Tim dosen pelaksana juga memberikan semangat dan motivasi agar para pelaku usaha dan binaan koperasi dapat terus berkembang dengan usaha yang dijalaninya.

Tabel di bawah ini akan menjelaskan secara detail kontribusi yang mampu diberikan tim dosen pelaksana kegiatan Pengabdian Masyarakat kepada para pelaku usaha kecial dan binaan koperasi setelah pelatihan dilaksanakan.

Tabel 4

Kontribusi dalam Kegiatan Pengabdian Masyarakat

\begin{tabular}{|c|c|c|}
\hline $\begin{array}{c}\text { Komponen } \\
\text { Kegiatan }\end{array}$ & Sebelum Kegiatan P2M & Setelah Kegiatan P2M \\
\hline $\begin{array}{l}\text { Kondisi keuangan } \\
\text { dan bisnis pelaku } \\
\text { usaha kecil dan } \\
\text { binaan koperasi }\end{array}$ & $\begin{array}{l}\text { Para pelaku usaha kecil dan } \\
\text { binaan koperasikurang } \\
\text { memiliki semangat dalam } \\
\text { berwirausaha serta masih } \\
\text { memiliki kemampuan yang } \\
\text { terbatas dalam mengelola } \\
\text { keuangan dengan baik dan } \\
\text { pengendalian pasar. } \\
\text { a. Para peserta menyatakan } \\
\text { bahwa dalam setiap } \\
\text { harinya banyak penge- } \\
\text { luaran tidak terduga } \\
\text { yang membuat ibu-ibu }\end{array}$ & $\begin{array}{l}\text { Para pelaku usaha kecil } \\
\text { dan binaan koperasi } \\
\text { mendapatkan } \\
\text { pengetahuan mengenai } \\
\text { cara mengelola keuangan } \\
\text { mereka dengan baik } \\
\text { melalui sebuah simulasi, } \\
\text { ditambah dengan berba- } \\
\text { gai tips, seperti: } \\
\text { a. Anggaran belanja } \\
\text { dibuat per bulan dan } \\
\text { bukan harian, teruta- } \\
\text { ma untuk kebutuhan }\end{array}$ \\
\hline
\end{tabular}




\begin{tabular}{|c|c|c|}
\hline $\begin{array}{c}\text { Komponen } \\
\text { Kegiatan }\end{array}$ & Sebelum Kegiatan P2M & Setelah Kegiatan P2M \\
\hline & $\begin{array}{l}\text { tersebut harus mengam- } \\
\text { bil uang simpanan yang } \\
\text { seharusnya menjadi ta- } \\
\text { bungan mereka, misal- } \\
\text { nya untuk keperluan } \\
\text { pergi ke acara undangan } \\
\text { pernikahan, ada anggota } \\
\text { keluarga yang sakit, dan } \\
\text { jajan anak yang sering- } \\
\text { kali tidak terkontrol } \\
\text { hingga mencapai Rp } \\
\text { 30.000/hari untuk anak } \\
\text { mereka yang masih } \\
\text { SMP. } \\
\text { b. Dikarenakan keterbata- } \\
\text { san pasar dan peminat } \\
\text { dalam pembelian daga- } \\
\text { ngan mereka, menyebab- } \\
\text { kan para pelaku usaha } \\
\text { tidak bersemangat da- } \\
\text { lam mencari alternatif } \\
\text { lain dalam usaha } \\
\text { c. Persaingan yang cukup } \\
\text { ketat dalam jenis usaha } \\
\text { yang dijalankan, sehing- } \\
\text { ga menyebabkan para } \\
\text { penjual kehilangan pe- } \\
\text { langgannya karena pin- } \\
\text { dah ke tempat lain } \\
\text { d. Untuk sembako dan } \\
\text { kebutuhan makan setiap } \\
\text { hari, ibu-ibu biasanya a- } \\
\text { kan mengeluarkan uang } \\
\text { sebesar Rp 40.000/hari, } \\
\text { ditambah dengan penge- } \\
\text { luaran tidak terduga, } \\
\text { yaitu jajan tambahan } \\
\text { apalagi jika ibu-ibu } \\
\text { membawa anak mereka }\end{array}$ & $\begin{array}{l}\text { primer, seperti semba- } \\
\text { ko (beras, minyak } \\
\text { goreng, gula pasir), } \\
\text { bensin, dan kebutu- } \\
\text { han mandi. } \\
\text { b. Ibu-ibu dapat lebih } \\
\text { membatasi uang jajan } \\
\text { yang diberikan kepa- } \\
\text { da anak-anak dan } \\
\text { menerapkan pola hi- } \\
\text { dup hemat secara } \\
\text { konsisten. } \\
\text { c. Para pelaku usaha } \\
\text { dan binaan koperasi } \\
\text { dapat mengatur jad- } \\
\text { wal dan jenis usaha- } \\
\text { nya agar tidak sama } \\
\text { jualannya dengan pe- } \\
\text { laku usaha lainnya } \\
\text { sehingga dapat mem- } \\
\text { peroleh pelanggan } \\
\text { yang tetap } \\
\text { d. Membiasakan diri me- } \\
\text { nabung di bank untuk } \\
\text { meminimalisir penge- } \\
\text { luaran tak terduga. }\end{array}$ \\
\hline
\end{tabular}




\begin{tabular}{c|l|l}
\hline $\begin{array}{c}\text { Komponen } \\
\text { Kegiatan }\end{array}$ & Sebelum Kegiatan P2M & Setelah Kegiatan P2M \\
\hline & $\begin{array}{l}\text { ke pasar. } \\
\text { e. Kebutuhan mandi, se- } \\
\text { perti pasta gigi, sabun, }\end{array}$ & \\
maupun sampo tidak & \\
& dianggarkan per bulan, & \\
namun langsung beli & saja saat masing-masing \\
& kebutuhan mandi terse- & \\
but habis. & \\
\hline
\end{tabular}

\section{KESIMPULAN DAN SARAN}

\section{Kesimpulan}

Berdasarkan hasil pelaksanaan kegiatan yang telah dilakukan, maka terdapat beberapa hal yang dapat disimpulkan dari kegiatan Pengabdian Pada Masyarakat (P2M) ini, yaitu:

1. Pengetahuan dan pemahaman peserta pelaku usaha kecil dan binaan koperasi masih rendah terkait dengan semangat berwirausaha dan bagimana mengelola keuangan

2. Pelatihan yang dilaksanakan mampu meningkatkan jiwa wirausaha dan motivasi para pelaku usaha dalam menjalankan usaha bisnisnya dengan baik dan optimal.

\section{Saran}

Adapun saran bagi peningkatan kualitas kegiatan Pengabdian Pada Masyarakat (P2M) ini, meliputi:

1. Para pelaku usaha kecil dan binaan koperasi hendaknya memilki pengetahuan dasar agar memiliki motivasi jiwa kewirausahaan dan mampu menerapkan cara pengelolaan keuangan secara konsisten

2. Evaluasi dan kontrol secara berkala kiranya dapat terus dilakukan untuk memantau apakah para pelaku usaha kecil dan binaan koperasi yang menjadi sasaran di Rusunawa Kelurahan Cipinang Besar Selatan Jakarta Timur, tetap memiliki motivasi dan semangat dalam berwirausaha serta mampu mengelola keuangan mereka sesuai dengan simulasi yang telah diberikan serta mulai menjalankan usaha

3. Kegiatan Pengabdian Pada Masyarakat dapat terus dikembangkan, yaitu dengan menambah pelatihan keterampilan yang dapat diaplikasikan sebagai peluang usaha, serta memperluas jangkauan sasaran hingga ke kawasan Jakarta lainnya.

\section{DAFTAR PUSTKA}

Agustina, Tri Siwi. 2015. Kewirausahaan: Teori dan 
Penerapan pada Wirausaha dan UKM di Indonesia. Jakarta: Mitra Wacana Media.

Chen, C: Patricia G. Greene: and And Crick. Does Entrepreneurial SelfEfficacy Distinguish Entrepreneurs from Managers? (Journal pf Business Venturing, vol 13, 1998)
Daryanto, Bintoro. 2014. Manajemen Diklat. Yogjakarta: Gava Media.

Zimmerer, Thomas W, Norman $M$. Scarborough. Essentials of Entrepreneurship an Small Bussinss Management. Fourth edition. New Jersey: Pearson Prentice Hall, 2005 